\title{
Management of small cell carcinoma of the bladder: Consensus guidelines from the Canadian Association of Genitourinary Medical Oncologists (CAGMO)
}

\author{
Patricia Moretto, MD; Lori Wood, MD, MSc, FRCPC; ${ }^{\dagger}$ Urban Emmenegger, MD; ${ }^{;}$Normand Blais, MD, MSc, \\ FRCPC,; Som Dave Mukherjee, MD, MSc, FRCPC,; Eric Winquist, MD, MSc, FRCPC, FACP,: Eric Charles \\ Belanger, MD, Robert MacRae, MD, FRCPC, Alexander Balogh, MD,; llias Cagiannos, MD, FRCPC;,

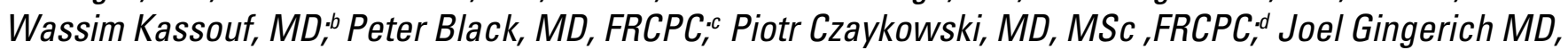 \\ FRCPC, , Scott North, MD, FRCPC, MHPE, Scott Ernst, MD, FRCPC,f Suzanne Richter, MD, MSc, FRCPC,f \\ Srikala Sridhar, MD, MSc, FRCPC, ${ }^{f}$ M. Neil Reaume, MD, MSc, FRCPC, ${ }^{*}$ Denis Soulieres, MD, MSc, FRCPC; \\ Andrea Eisen MD, FRCPC;, Christina M. Canil, MD, FRCPC*
}

*Department of Medicine, Division of Medical Oncology, The Ottawa Hospital Cancer Centre, The Ottawa Hospital Research Institute, University of Ottawa, Ottawa, ON; 'Division of Medical Oncology, Queen Elizabeth II Health Sciences Centre, Halifax, NS; §Division of Medical Oncology, Odette Cancer Centre, Sunnybrook Research Institute, Toronto, ON; : thematology and Medical Oncology Service, Department of Medicine, Centre Hospitalier de I'Université de Montréal, Montreal, QC; ${ }^{*}$ Division of Medical Oncology, Juravinski Cancer Centre, Hamilton, ON; £Division of Medical Oncology, London Health Sciences Centre, London, ON; : Department of Pathology and Laboratory Medicine, Division of Anatomical Pathology, The Ottawa Hospital, University of Ottawa, Ottawa, ON; ${ }^{\beta}$ Division of Radiation Oncology, The Ottawa Hospital Cancer Centre, The Ottawa Hospital Research Institute, University of Ottawa, Ottawa, ON; " Division of Radiation Oncology, Tom Baker Cancer Centre, Calgary, AB; 'Division of Urology, The Ottawa Hospital, University of Ottawa, Ottawa, ON; bDivision of Urology, McGill University Health Centre, Montreal, QC; 'British Columbia Cancer Agency, Vancouver, BC; dDivision of Medical Oncology, Cancer Care Manitoba, University of Manitoba Winnipeg, MB; eCross Cancer Institute, Department of Oncology, University of Alberta, Edmonton, AB; fPrincess Margaret Hospital, University Health Network, Toronto, ON

Cite as: Can Urol Assoc J 2013;7:E44-E56. http://dx.doi.org/10.5489/cuaj.220

\section{Introduction}

Small cell carcinomas (SCC) most commonly arise from the lung. ${ }^{1}$ These tumours are aggressive, present with early metastasis and are associated with a poorer prognosis compared to non-small cell lung cancer. ${ }^{2,3}$ Extra-pulmonary SCC was first described by Duguid and Kennedy in $1930^{4}$ and subsequently has been reported in the gastrointestinal tract, ${ }^{5}$ head and neck ${ }^{6}$ and genitourinary (GU) system.

SCC of the GU system (SCCGU) are uncommon, but can occur in the kidneys, ${ }^{8}$ renal pelvis, ${ }^{9}$ ureter, ${ }^{10}$ bladder, ${ }^{7}$ urachus, ${ }^{11}$ urethra ${ }^{12}$ and prostate..$^{13}$ Although rare, these cancers are not insignificant. SCC accounts for $0.5 \%$ to $0.7 \%$ of all bladder cancers diagnosed. ${ }^{14,15}$ SCCGU also behaves more aggressively than typical GU histological counterparts. ${ }^{16}$ There is little medical literature to guide the optimal management of SCCGU malignancies and therefore treatment paradigms have by default mirrored those of the more common small cell carcinoma of the lung. Given the rarity of SCCGU tract and the lack of good clinical guidelines, it was clear that a guideline to help Canadian physicians and surgeons manage these patients with SCCGU was needed.
This document achieves that goal for small cell carcinoma of the bladder (SCCB).

\section{Material and methods}

We systematically reviewed English publications through MEDLINE/PubMed from 1946 to the present. Bibliographies from the relevant papers were also searched. Keywords were used alone and with the modifiers to small cell carcinoma, genitourinary, neuroendocrine carcinoma, and urinary bladder neoplasms. Two reviewers (PM,CC) independently assessed data for relevant trials, with the aim to minimize bias. Decisions about study inclusion were made independently, and consensus was used to resolve any discrepancy. The initial search identified 116 papers: 47 papers relevant to SCCB and 5 for SCCGU. Most $(n=36)$ of the SCCB papers were small case series/case reports $(n \leq 20)$, with only 2 prospective trials. Criteria for study selection included study design, relevance to clinicians, number of cases reported and preferably no prior publications accounting for the same cases. Pertinent studies presented at the annual meetings of American Society of Clinical Oncology (ASCO) and the European Society for Medical Oncology (ESMO) were also reviewed. A search was also performed for any published guidelines or consensus statements on management of SCCB 
or SCCGU. Only one guideline was identified, from the National Cancer Care Network (NCCN). The grading system used for our recommendations is based on the Oxford Centre for Evidence-based Medicine. ${ }^{17}$

Compilation of this data was presented in June 2011 at the 6th Annual Meeting of the Canadian Association of Genitourinary Medical Oncologists (CAGMO). The group drafted a consensus guideline to address issues of diagnosis, staging, treatment and follow-up of SCCB (SCC of the prostate was also discussed and this consensus guideline will be presented at a later date). Further discussions have since occurred throughout the year, at the 2012 CAGMO meeting, as well as with Canadian experts in urology (IC,WK,PB), radiation oncology $(\mathrm{RM}, \mathrm{AB})$ and pathology $(\mathrm{EB})$. The AGREE II (Appraisal of Guidelines, Research and Evaluation) ${ }^{18,19}$ instrument was completed by all authors to evaluate and enhance the quality of this document. This guideline will be updated every 4 years at future CAGMO meetings.

\section{Small cell carcinoma of the bladder}

\section{Epidemiology/presentation}

The first case of primary SCCB was reported in $1981 ;{ }^{7}$ since then, no more than 1000 cases have been published. These cases are primarily reported as small case series. As in urothelial carcinoma of the bladder (UCB), the mean age is 65 years, with male predominance, and an association with smoking. ${ }^{20-22}$ Analogous to UCB, presenting symptoms of SCCB are often related to the presence of a bladder mass and include hematuria, ${ }^{14,15,20,23,24}$ dysuria, nocturia, frequency, urinary obstructive symptoms and localized abdominal/ pelvic pain. ${ }^{14,22,23,25}$ However, the natural history of SCCB is more aggressive and is associated with poorer prognosis than UCB. Therefore, in most cases, SCCB will be locally advanced or metastatic ${ }^{20-23,26-29}$ at diagnosis and follow a pattern of metastases similar to UCB. The most common sites of spread are regional and distant lymph nodes, liver and bones. ${ }^{22}$ However, in contrast to $U C B$, lung is a site of late metastasis in SCCB. ${ }^{22}$ The occurrence of brain metastasis in SCCB can vary from 0 to $40 \%$, but data from a large retrospective series of 342 patients describe a cumulative incidence of $11 \%$ (95\% Cl $7.5 \%$ to $14.1 \%) .{ }^{30}$ Once brain metastases develop, the prognosis is dismal (life expectancy $<2$ months). ${ }^{31}$

SCC lung cancer (SCLC) has been associated with paraneoplastic syndromes, such as hyponatremia, Cushing's Syndrome, Lambert-Eaton myasthenic syndrome, neuropathy, hypophosphatemia, hypercalcemia, and nephrotic syndrome. ${ }^{22,32}$ These paraneoplastic syndromes appear less common in SCCB compared to SCC of the lung or prostate. ${ }^{33}$

\section{Pathological diagnosis}

The differential diagnosis of SCCB is quite broad and includes poorly differentiated urothelial carcinoma, poorly differentiated squamous cell carcinoma, lymphoma, lymphoepithelioma-like carcinoma, plasmacytoid carcinoma, large cell neuroendocrine carcinoma, SCLC metastatic to the bladder or SCC of the prostate invading into the bladder. The presence of concurrent urothelial carcinoma in the specimen often corroborates the pathological diagnosis of a bladder primary.

As $\mathrm{SCCB}^{34}$ and SCLC share similar histology, the diagnosis of SCCB is based on the same World Health Organization (WHO) criteria. ${ }^{35}$ The tumour consists of sheets or nests of small or intermediate round cells with nuclear moulding, scant cytoplasm containing few organelles, inconspicuous nucleoli and evenly dispersed "salt-and-pepper chromatin." 23 Other common features include a high mitotic rate and tumour necrosis. ${ }^{14,23,36}$ Dense core neurosecretory granules can be demonstrated by electron microscopy. Crush artifact (Azzopardi effect) is frequently seen, which can make the diagnosis difficult in small biopsy specimens. ${ }^{23}$ The presence of vascular invasion is variable, ${ }^{23,34,37}$ but most tumours extensively infiltrate the detrusor muscle. ${ }^{34}$

The incidence of pure SCCB varies from $12 \%$ to $61 \%{ }^{20,22,23}$ However, SCCB more commonly coexists with other histologies, such as urothelial carcinoma, adenocarcinoma, squamous cell carcinoma and sarcomatoid-urothelial carcinoma. ${ }^{20,28,38}$ Patients with a small cell component to their bladder tumour have a worse clinical outcome than patients with conventional UCB..$^{15,29,24,39}$ In addition, patients with a pure SCCB have a median overall survival for nonmetastatic, metastatic or recurrent disease (4.5-9.5 months) that is 2 to 3 times shorter compared to mixed SCCB. ${ }^{21,26}$

Immunohistochemical staining is important to support a diagnosis of SCCB, which typically exhibits both epithelial and neuroendocrine differentiation. Several different tumour markers of neuroendocrine differentiation have been demonstrated in $30 \%$ to $100 \%$ of cases of SCCB, with variable results across studies. ${ }^{23,40-42}$ Neuron-specific enolase (NSE) (25-100\%), chromogranin A (22-89\%), synaptophysin (67-76\%), CD57, CD56, and protein gene product 9.5 (PGP9.5) $14,23,40,41,43$ are markers that are often focally or diffusely positive in tumours with neuroendocrine differentiation.

Epithelial markers are often positive in SCCB, and include cytokeratin (CK) 7 in about $60 \%$ of cases, ${ }^{44}$ and epithelial membrane antigen (EMA) in almost $80 \%$ of cases. ${ }^{14}$ CK20 is usually negative..$^{44,45}$ Low molecular weight cytokeratins, like CAM5.2 or CK8/18, can be positive in both SCCB and UCB, but often have different staining patterns: SCCB usually stains in a punctate perinuclear pattern, while UCB stains in a membranous pattern. ${ }^{46}$ To differentiate SCCB and Non- 
Hodgkin lymphomas by immunohistochemistry, the latter are usually CD45 positive and CK negative.

Thyroid transcription factor 1 (TTF-1) is usually negative in UCB. It is, however, positive in more than $85 \%$ of SCLC, ${ }^{47}$ and can be also positive in up to $50 \%$ of SCCB. ${ }^{43,44}$ TTF- 1 does not help in the diagnosis of the primary site of SCC, but it may help to differentiate SCCs from urothelial carcinomas in situations when histopathology reports a poorly differentiated tumour.

In general, cytokeratin immunohistochemistry is not helpful in distinguishing the site of origin, specifically between a lung and bladder primary. ${ }^{48}$ Both SCLC and SCCB can be CK7 positive and are usually CK20 negative. ${ }^{49}$ Ultimately, the diagnosis can be made based on the morphology alone for most of the cases, even if neuroendocrine differentiation cannot be demonstrated. $23,40,41,50$

\section{Molecular abnormalities and biomarkers of $\mathrm{SCC}$ of the bladder}

In SCCB, Soriano and colleagues demonstrated positive immunostaining for p53 in $80 \%$ and for C-erbB2 in $50 \%$ of cases. ${ }^{41}$ Other transmembrane tyrosine kinase receptors, c-kit $(\mathrm{CD} 117)^{23,51}$ and $\mathrm{EGFR}^{23,52}$ have been shown to be positive in about $30 \%$ of cases of SCCB. ${ }^{41}$ These receptors may represent new therapeutic targets. However, in SCLC, despite the identification of biomarkers, such as p53, $\beta 1$-integrin, bcl-2, ERCC1, RRM1, IL-2, bax, BCRP and c-kit, the predictive and prognostic value of these makers is controversial and to date has not affected clinical decision-making. ${ }^{47}$ Similarly, in SCCB, the expression of p53 varies from $37 \%$ to $80 \%,{ }^{40,41,53}$ yet prognosis appears poor in both p53 expressing and nonexpressing tumours. ${ }^{54}$

\section{Staging system}

In the management of SCLC, a simplified staging approach known as the Veterans Affairs system separating "limited" and "extensive" disease was initially adopted. ${ }^{55}$ Limited disease (LD) refers to tumours confined to one hemithorax and with all the disease encompassable within the same radiation field (i.e., potentially curable). Disease spread beyond the affected hemithorax and a reasonable radiation field is defined as extensive disease (ED) (i.e., incurable). In our literature search, LD versus ED was the most commonly used staging system for SCCB. In contrast to typical SCLC treatment, resection of the primary tumour can be part of the therapeutic armamentarium in SCCB. Therefore, the resectability of the primary tumour should be taken into consideration when designating LD versus ED.

More recently, the International Association for the Study of Lung Cancer (IASLC) has recommended the use of the Tumor-Node-Metastases (TNM) staging system for SCLC to better group patients according to their prognosis. ${ }^{56}$ Given that the TNM classification is also used for staging of UCB, and as SCCB is frequently diagnosed in combination with $U C B$, some authors use the TMN staging system to report their SCCB cases (Table 1). ${ }^{57}$

\section{Staging investigations}

The choice of appropriate staging investigations for SCCB should help determine the extent of the disease and take into consideration the pattern of metastatic spread to the distant lymph nodes, liver, bone and, less commonly, lung and brain. Again, imaging modalities used in SCLC and UCB serve as a model.

Traditionally, to assess for local disease, computerized tomography $(\mathrm{CT})$ of the chest and abdomen constitutes the main staging modality for SCLC. ${ }^{58}$ The staging for primary disease in UCB consists of abdomen and pelvis CT with contrast, including delayed images to identify defects in the collecting system (CT urography). ${ }^{59}$ Gadolinium-enhanced magnetic resonance imaging (MRI) of the pelvis displays comparable accuracy to $\mathrm{CT}$ for finding non-organ confined bladder cancer, ${ }^{60,61}$ however, MRI has a higher sensitivity for extra-vesical tumour extension and adjacent organ invasion. ${ }^{62}$ Therefore, MRI may be helpful if radical cystectomy is being considered.

For more distant disease, CT scans are used to assess for lung and liver metastases and 99mTc-MDP bone scans are routinely performed to assess for bone metastases. ${ }^{58}$ Gadolinium-enhanced MRI or contrast-enhanced CT scans are used to identify brain metastases, although MRI is more sensitive. ${ }^{63,64}$

\section{Pathological diagnosis}

Recommendation:

Pathology should be reviewed at a tertiary centre if there is a suspicion of a small cell component. Percentage of small cell component, as well as other histological features of the tumour, should be reported. Level 4 Grade $C$

Immunohistochemistry should be attempted to demonstrate neuroendocrine differentiation, but more importantly to rule out other possible neoplasms, specifically lymphoma. This panel should include the following: CD56, synaptophysin, CD45, low molecular weight cytokeratin (CAM5.2 or CK8/18). In cases where neuroendocrine differentiation cannot be demonstrated and where lymphoma has been ruled out, additional markers could be performed and include, but are not limited to, CK7, CK20 and TTF-1. Level 4 Grade C 


\begin{tabular}{|c|c|c|c|}
\hline Stage: & $\mathbf{T}$ & $\mathbf{N}$ & M \\
\hline & $\begin{array}{l}\text { Tx: Primary tumour cannot be assessed } \\
\text { T0: No evidence of primary tumour }\end{array}$ & Nx: Lymph nodes cannot be assessed & \\
\hline $0 \mathrm{a}$ & Ta: Noninvasive papillary carcinoma & N0: No regional lymph node metastasis & $\begin{array}{l}\text { M0: No distant } \\
\text { metastasis }\end{array}$ \\
\hline Ois & Tis: Carcinoma in situ: "flat tumour" & No & Mo \\
\hline 1 & T1: Tumour invades subepithelial connective tissue & No & Mo \\
\hline \multirow{2}{*}{ II } & pT2a: Tumour invades superficial muscularis propria (inner half) & No & Mo \\
\hline & pT2b: Tumour invades deep muscularis propria (outer half) & No & Mo \\
\hline \multirow{3}{*}{ III } & pT3a: Tumour invades perivesical tissue microscopically & No & Mo \\
\hline & $\begin{array}{l}\text { pT3b: Tumour invades perivesical tissue macroscopically } \\
\text { (extravesical mass) }\end{array}$ & No & Mo \\
\hline & $\begin{array}{l}\text { T4a: Tumour invades prostatic stroma, seminal vesicle, uterus, } \\
\text { or vagina }\end{array}$ & No & Mo \\
\hline \multirow{5}{*}{ IV } & T4b: Tumour invades pelvic wall, abdominal wall & No & Mo \\
\hline & \multirow{3}{*}{ Any $\mathrm{T}$} & $\begin{array}{l}\text { N1 Single regional lymph node metastasis } \\
\text { in the true pelvis (hypogastric, obturator, } \\
\text { external iliac or presacral lymph node) }\end{array}$ & Mo \\
\hline & & $\begin{array}{l}\text { N2: Multiple regional lymph node metastases } \\
\text { in the true pelvis (hypogastric, obturator, } \\
\text { external iliac or presacral lymph node) }\end{array}$ & Mo \\
\hline & & $\begin{array}{l}\text { N3: Lymph node metastases to the common } \\
\text { iliac lymph nodes }\end{array}$ & Mo \\
\hline & Any $\mathrm{T}$ & Any N & $\begin{array}{l}\text { M1: Distant } \\
\text { metastasis }\end{array}$ \\
\hline
\end{tabular}

The role of 18F-FDG positron emission tomography/CT (FDG-PET/CT) imaging in SCCB is not clear. Some guidelines recommend FDG-PET/CT for staging in patients with possibly limited SCLC who are potential candidates for curative treatment with the addition of thoracic radiotherapy to chemotherapy. ${ }^{65}$ However, even though PET/CT outperforms conventional imaging in adequately staging the primary tumour in SCLC, the role of PET/CT is uncertain in the evaluation of mediastinal and extrathoracic nodes and distant metastasis due to discordance when compared to other diagnostic methods. ${ }^{66,67}$

\section{Treatment}

Given that SCCB is rare, there is a paucity of good quality clinical trials and therefore no standard treatment. Literature review identified 43 retrospective series and case reports, the majority being quite small (range: $1-663$ patients). ${ }^{68}$ The only prospective studies were a non-randomized phase II study ${ }^{31}$ and a single-centre study of 25 cases treated in a fashion analogous to SCLC. ${ }^{28}$ The National Cancer Care Network $(\mathrm{NCCN})^{69}$ was the only identified guideline which included SCCB.

These studies used many different treatment approaches for SCCB. ${ }^{70,71}$ Treatment modalities included chemotherapy alone, neoadjuvant chemotherapy followed by cystectomy, cystectomy followed by adjuvant chemotherapy, cystectomy alone, transurethral resection of bladder tumour (TURBT) alone, radiotherapy alone and finally concurrent or sequential chemotherapy and radiotherapy. Therefore, in some instances the treatment was similar to SCLC (chemotherapy for ED; combination chemotherapy and radiation

\section{Staging system}

Recommendation: The panel recommends the two stage system (i.e., limited disease [LD] vs. extensive disease [ED]) for staging of SCCB based on the Veterans Affairs system initially established for SCLC.

LD is defined as tumour restricted to the bladder, with or without locoregional lymph nodes, which:

1) can be resected or

2) is confined to the true and false pelvis such that all disease is encompassable within the same radiation field.

ED is defined as disease which does not fall into the above description. However, the TNM should be also done for the purposes of registry and participation in clinical trials. Level 4 Grade $C$ 


\section{Staging investigations}

Recommendation: Suggested staging investigations include: contrast-enhanced computerized tomography (CT) of thorax, abdomen and pelvis and brain imaging (magnetic resonance imaging [MRI] or CT with contrast if MRI contraindicated or not-available). 99mTc-MDP bone scan should be performed in patients with bony symptoms, and considered in asymptomatic ones.

If disease is limited and curative local treatment is planned, gadolinium-enhanced MRI of the pelvis may be helpful to confirm resectability or extent of the radiation field. At this time, FDG-PET/CT could be considered under special circumstances to identify metastatic disease outside of the radiation field but would not be considered standard of care. Level 4 Grade $C$

for LD). In other cases, treatment for localized disease was more similar to UCB (cystectomy with neoadjuvant/adjuvant chemotherapy). The NCCN guideline ${ }^{69}$ recommends treating LD SCCB with neoadjuvant or adjuvant chemotherapy using the same regimens that are used in SCLC (i.e., platinum doublet), along with local therapy consisting of cystectomy or radiation. For ED, the recommendation is to administer regimens similar to those used in SCLC, such as cisplatin or carboplatin in combination with etoposide or irinotecan. ${ }^{72}$

Table 2. Papers describing exclusively limited disease

\begin{tabular}{|c|c|c|c|c|c|c|c|c|c|c|}
\hline Author & Institution & $\mathbf{N}$ & Stage & Chemotherapy & $\mathbf{S}$ & $\begin{array}{l}\text { Chemo/ } \\
\text { RXT }\end{array}$ & Chemo/S & $\mathbf{R R}$ & mOS & $\begin{array}{l}\text { Local } \\
\text { recurrence }\end{array}$ \\
\hline Lynch $^{72}$ & $\begin{array}{c}\text { MD } \\
\text { Anderson }\end{array}$ & $125^{€}$ & LD & $\begin{array}{c}\text { EP/IA; MVAC; } \\
\text { EP; TMP; } \\
\text { CGI; EAP; IA; } \\
\text { GCTx, GTA; } \\
\text { CaE, VACTx, } \\
\text { 5-FUCarbo }\end{array}$ & $\begin{array}{c}26 \\
(27 \%)\end{array}$ & 6 & $\begin{array}{c}48 \\
\text { neadjuvant } \\
(51 \%) \\
21 \\
\text { adjuvant } \\
(22 \%)\end{array}$ & $\begin{array}{c}62 \% \\
\text { downstaging } \\
\text { in the } \\
\text { neadjuvant }\end{array}$ & $\begin{array}{c}\text { Neo: } \\
\text { with } \\
\text { downstaging } \\
187 \text { mos; no } \\
\text { downstaging } \\
10.8 \text { mos; } \\
\text { Surgery or } \\
\text { adjuvant } \\
\text { chemo: } 18.3 \\
\text { mos }\end{array}$ & NA \\
\hline Alva $^{97}$ & $\begin{array}{l}\text { University } \\
\text { of } \\
\text { Michigan }\end{array}$ & 20 & LD & $\begin{array}{c}E P \text {, other } \\
\text { platinum-based }\end{array}$ & --- & $1(5 \%)$ & $\begin{array}{c}19 \\
\text { neadjuvant } \\
(95 \%)\end{array}$ & NA & All: 40 mos & $5(25 \%)$ \\
\hline Ismaili'i & $\begin{array}{l}\text { Léon- } \\
\text { Bérard } \\
\text { Cancer } \\
\text { Centre }\end{array}$ & 14 & $\begin{array}{c}\text { non- } \\
\text { metastatic }\end{array}$ & EP & $5(36 \%)$ & $1(7 \%)$ & $\begin{array}{c}2 \\
\text { neadjuvant } \\
(14 \%) \\
4 \operatorname{adj}(29 \%)\end{array}$ & NA & $\begin{array}{l}\text { All: } 29.5 \text { mos } \\
\text { Combined T: } \\
38.6 \text { mos }\end{array}$ & $1(7 \%)$ \\
\hline $\mathrm{Bex}^{* 38}$ & NKI & 42 & LD & $\begin{array}{c}\text { VIP; EP; } \\
\text { MVAC; cyclo- } \\
\text { phosphamide, } \\
\text { doxorubicin and } \\
\text { etoposide; and } \\
\text { CaE }\end{array}$ & $\begin{array}{l}\text { TURBT } \\
(100 \%)\end{array}$ & $\begin{array}{c}16 \\
(94 \%)^{£}\end{array}$ & --- & $\begin{array}{l}15 \text { CR (94\%) } \\
1 \text { PR (6\%) } \\
\text { All: } 32.5 \text { mos }\end{array}$ & All: 32.5 mos & $4(25 \%)$ \\
\hline $\begin{array}{l}\text { Siefker- } \\
\text { Radtke }^{29}\end{array}$ & $\begin{array}{c}\text { MD } \\
\text { Anderson }\end{array}$ & $88^{*}$ & LD (69\%) & $\begin{array}{l}\text { EP; IA; } \\
\text { MVAC; taxol, } \\
\text { methotrexate } \\
\text { and cisplatin }\end{array}$ & $\begin{array}{c}25 \\
(41 \%)\end{array}$ & --- & $\begin{array}{c}21- \\
\text { neadjuvant } \\
(34 \%) \\
7 \text { adjuvant } \\
(11 \%)\end{array}$ & 12 (57\%) & $\begin{array}{c}\text { Surgery: } 23 \\
\text { mos } \\
\text { Combined T: } \\
\text { not reached }\end{array}$ & $\begin{array}{c}5 \text { (of 55) } \\
(9 \%)\end{array}$ \\
\hline Lohrisch ${ }^{25}$ & $\mathrm{BCCA}$ & $14^{\S}$ & $\begin{array}{l}\text { localized } \\
1 \mathrm{ED}\end{array}$ & EP; PAVE; CMV & $\begin{array}{c}1 \\
\text { Surgery } \\
(7 \%) \\
9 \\
\text { TURBT } \\
(64 \%)\end{array}$ & $\begin{array}{c}10 \\
(71 \%)\end{array}$ & --- & 9 CR (64\%) & $\begin{array}{c}\text { All: } 26 \text { mos } \\
\text { Combined T: } \\
41 \text { mos }\end{array}$ & $2(14 \%)$ \\
\hline \multicolumn{11}{|c|}{$\begin{array}{l}\text { S: surgery; Chemo/RXT: chemotherapy combined with radiotherapy; Chemo/S: chemotherapy combined with surgery; Combined T: combined treatment; RR: response rate; mOS: median } \\
\text { overall survival; CR: complete response, NA: not available; TURBT: transurethral resection of bladder tumour; EP: cisplatin+etoposide; IA: ifosfamide+doxorubicin; MVAC: methotrexate+vinbl } \\
\text { astine+adriamycin+cisplatin; TMP: paclitaxel+methotrexate+cisplatin; CGI: cisplatin+gemcitabine+ifosfamide; EAP: etoposide+doxorubicin+cisplatin; GCTx: gemcitabine+cyclophosphamide; } \\
\text { GTA: gemcitabine+doxorubicin+paclitaxel; CaE: carboplatin+etoposide; VACTx: vincristine+doxorubicin+cyclophospahmide; 5-FUCarbo: 5-fluorouracil+carboplatin; PAVE: cisplatin+doxoru } \\
\text { bicin+vincristine+etoposide; CMV: cyclophosphamide+methotrexate+vinblastine; VIP: vindesin+ifosfamide+cisplatin; BCCA: British Columbia Cancer Agency; NKI: The Netherlands Cancer } \\
\text { Institute. }\end{array}$} \\
\hline
\end{tabular}




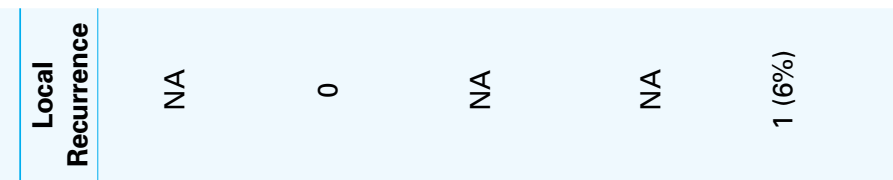

$\mathbb{s} \quad \mathbb{z}$

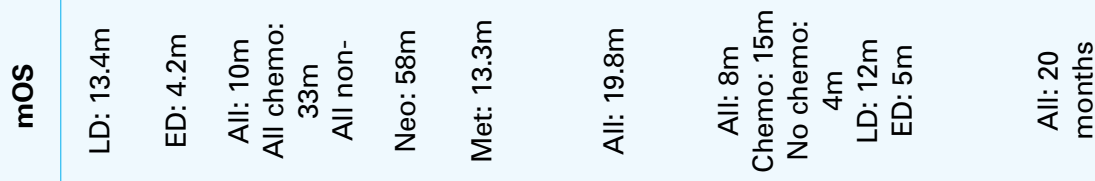

$\varangle$

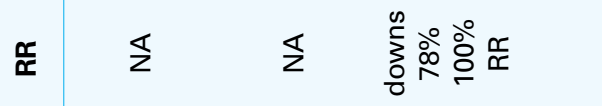

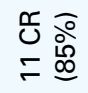

$\mathbb{s} \quad \mathbb{s}$

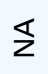

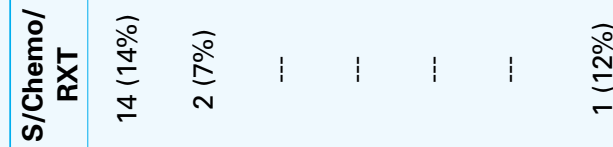

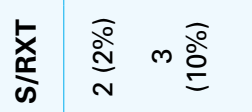

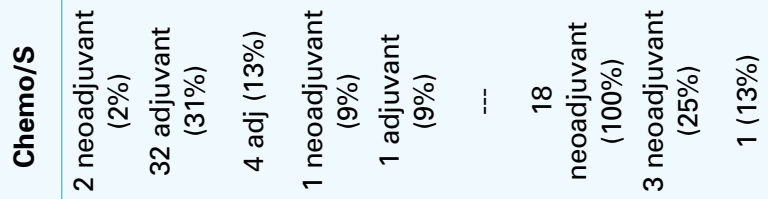

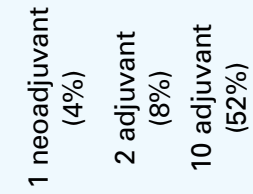

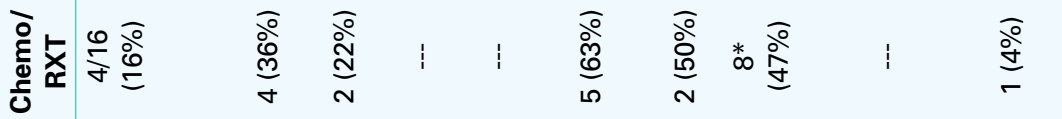

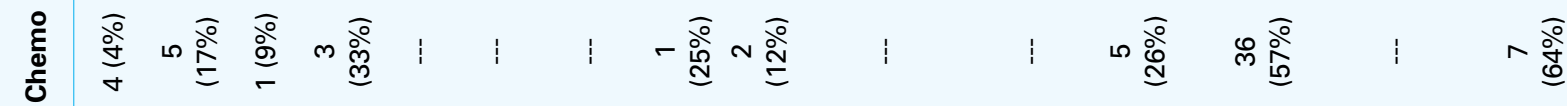

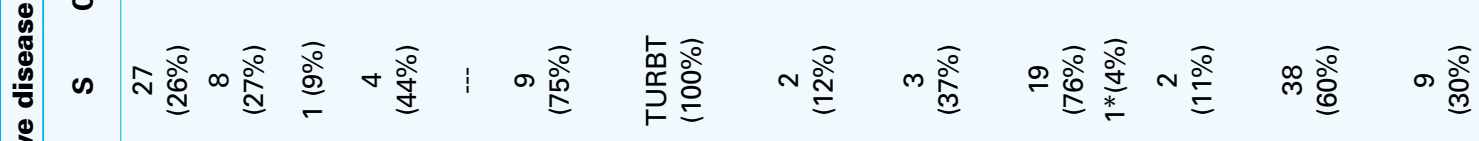

产

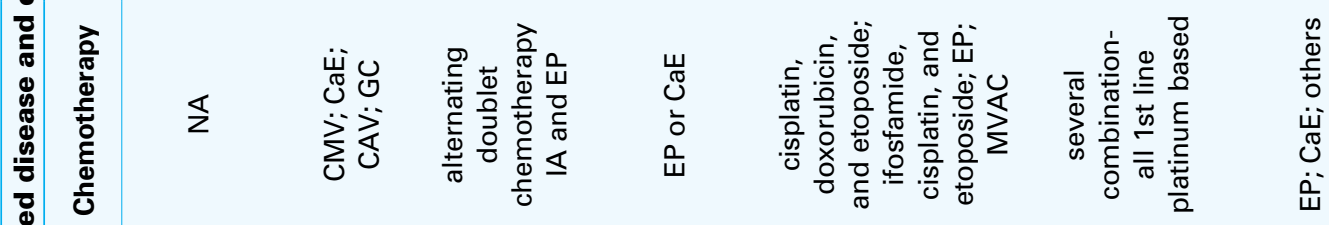

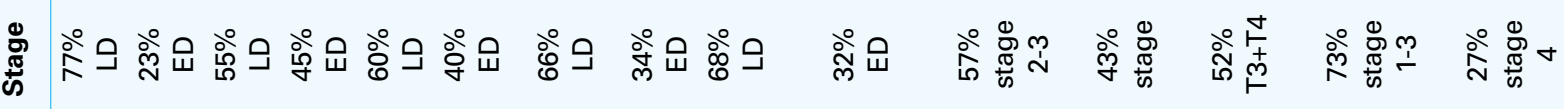

ำ

ก

\&

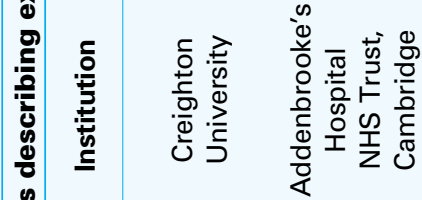

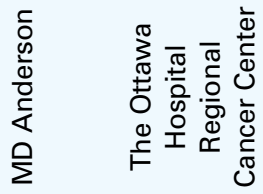

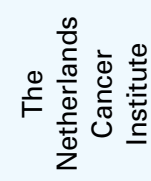

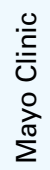

₹

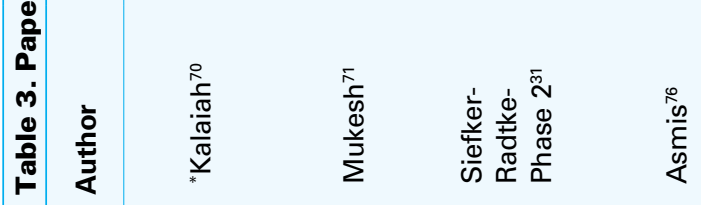

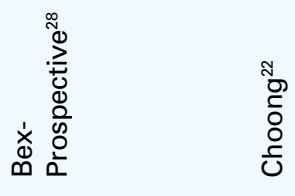

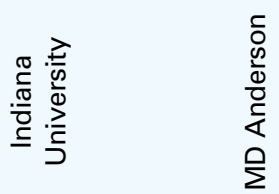

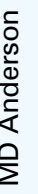

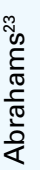

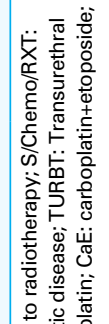

힌

है है.

至

혼 은

艾焉

空苍

言

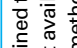

है을

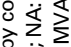

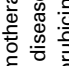

要

要

这

言悹这

寄产 
Table 2 and Table 3 summarize the most relevant papers identified and discussed by the consensus group. Based on this data, we observed that the approaches varied according to the stage of disease, institutional practice and year in which patients were treated. In addition, patient comorbidities/ability to tolerate specific therapies or patient/physician preference also influenced treatment plans. ${ }^{22}$ The chemotherapy regimens were generally platinum-based. In the case of LD SCCB, chemotherapy was administered (neo) adjuvantly to surgery, as well as in combination with radiation. In contrast to ED SCLC, combined treatment modalities were also applied to patients with ED SCCB. The median overall survival was better for LD (12-83 months) compared with ED (4-13 months).

\section{Treatment of limited disease}

Six papers were identified (Table 2) addressing more specifically LD (14-96 patients/study, $\mathrm{n}=203$ with LD). The most common treatment was chemotherapy given neoadjuvantly or adjuvantly with surgery $(n=122)$. However, the definition of surgery varied between the extremes of transurethral resection of the bladder tumour (TURBT) and radical cystectomy. When we reviewed trials combining patients with LD and ED (Table 3), most patients with LD were treated with the combination of chemotherapy and surgery. The second most common approach to treat LD was combined chemotherapy and radiation (Table 2, Table 3). Both (chemotherapy+surgery and chemotherapy+radiation) resulted in a clinical response and/or downstaging of disease: $57 \%$ for neoadjuvant chemotherapy in the retrospective analysis by Siefker-Radtke and colleagues; ${ }^{29} 78 \%$ in the phase II study done by the same authors, ${ }^{31}$ and $100 \%$ and $85 \%$ for chemoradiation in the retrospective study ${ }^{38}$ and prospective study by Bex and colleagues, ${ }^{28}$ respectively.

\section{Surgery}

The definition of surgical intervention was variable, including TURBT and radical cystectomy. TURBT involves the resection of all visible tumour if possible, including sampling of detrusor (muscularis propria) to properly access the pathology and staging of disease. ${ }^{73}$ TURBT is definitive therapy for non-invasive $U C B$, but patients with muscleinvasive disease require further management. Several of the reviewed studies of SCCB considered TURBT a definitive form of surgical local therapy for LD. However, TURBT is inadequate for local control of SCCB due to the aggressive nature of this disease. In the Surveillance, Epidemiology, and End Results (SEER) data, ${ }^{68}$ patients who had only biopsy or TURBT, had a median overall survival of only 11 months $(95 \% \mathrm{Cl}, 9.3-12.7)$. The remaining studies in our review of LD SCCB used TURBT as a diagnostic/ therapeutic procedure that preceded definitive local therapy as done in UCB. ${ }^{74}$

Koay and colleagues ${ }^{75}$ evaluated a large number of patients $(n=533)$ with SCCB, identified through the SEER database, over 15 years (1991-2005). In this analysis, cystectomy alone was more common than combined modalities. However, the rates of cystectomy have decreased from $37 \%$ (1991-1995) to $21 \%$ (2001-2005).

\section{Neoadivvant and adjuvant chemotherapy with surgery}

Combined treatment modalities, primarily based on retrospective studies, resulted in better median overall survival, up to 159.5 months with chemo-surgery versus 18 to 23 months with surgery alone. . $^{20,29,31,72}$ Siefker-Radtke and colleagues ${ }^{31,29,72}$ advocate for combining chemotherapy with surgery based on retrospective and phase II studies.

In a retrospective review by Lynch and colleagues, ${ }^{72} 172$ patients with SCCB were identified. Of the 95 patients eligible for surgery, 48 received neoadjuvant chemotherapy, while 47 had initial cystectomy (21/47 received adjuvant chemotherapy). Median overall survival in the neoadjuvant group was 159.5 months $(95 \% \mathrm{Cl}, 74.8-\infty)$ compared to 18.3 months $(95 \% \mathrm{Cl}, 14.8-25.5)$ for the group receiving initial cystectomy. For the $36 / 48$ patients who obtained downstaging to $\leq \mathrm{pT} 2 \mathrm{~N} 0 \mathrm{M} 0$ with neoadjuvant treatment, the median overall survival was 187 months $(95 \% \mathrm{Cl}, 160-\infty)$, prolonging the median overall survival results for the entire neoadjuvant group. Survival results for the 21 patients who received adjuvant chemotherapy (median overall survival 18.1 months) were similar to the 26 patients treated with cystectomy alone (18.3 months).

In the phase II trial by Siefker-Radtke and colleagues, ${ }^{31}$ 30 patients were enrolled to assess the addition of neoadjuvant chemotherapy [alternating cisplatin/etoposide (EP) and ifosfamide/doxorubicin] to cystectomy. Only $60 \%(18 / 30$ patients) had LD. All the 18 patients with LD, in addition to 3 initially metastatic patients who had a complete clinical response to chemotherapy, underwent surgery. The benefits of neoadjuvant chemotherapy were not restricted to simply downstaging, but resulted in an improvement in median overall survival (58 months for patients who went on to cystectomy vs. 13.3 months for patients treated with chemotherapy alone). Patients who were downstaged to pT2 had no cancer-related deaths after at least 2 years of follow-up. With regard to optimal chemotherapy regimens, neuroendocrine regimens or those used to treat SCCB (EP or ifosfamide/ doxorubicin) seemed to be more effective against the small cell component compared with regimens typically used for UCB (cisplatin/gemcitabine or methotrexate, vinblastine, doxorubicin, and cisplatin [MVAC]). ${ }^{29}$ Therefore, the MD Anderson Cancer Centre retrospective review and the phase II study by Siefker-Radtke and colleagues demonstrated: (1) 
benefit with neoadjuvant chemotherapy and (2) no improvement with adjuvant chemotherapy.

In the retrospective review by Cheng and colleagues, there was no significant difference in overall survival between patients who did or did not undergo cystectomy for local treatment. Still, a 1-year disease specific survival of $66 \%$ versus $45 \%$ was observed among patients who received combination therapy (surgery and chemotherapy), compared to those who underwent cystectomy alone. ${ }^{20}$ This highlights the role of systemic therapy in this disease.

\section{Bladder-sparing therapy: Chemotherapy and radiation}

Several series treated LD SCCB with bladder-sparing chemotherapy and radiation. ${ }^{25,28,38,76}$ However, the regimens/ doses/schedules were variable, and frequently not described. For $U C B$, radiation, alone or in combination with chemotherapy, is usually given as 40 to 46 Gy in 20 to 23 fractions to the whole pelvis and a boost of 20 Gy in 10 fractions to the bladder. ${ }^{77,78}$ For SCCB, the radiation doses used in combined modality varied from $35 \mathrm{~Gy} / 20,{ }^{25}$ to $64 \mathrm{~Gy} / 32$, to $70 \mathrm{~Gy},{ }^{15,25,28,79}$ with the mean dose being $60 \mathrm{~Gy}^{28,76}$ and the target area rarely described. ${ }^{28,76}$ Intensity modulated radiation therapy (IMRT) is a newer method of radiation delivery which has been used in pelvic tumours to minimize the radiation damage to nearby organs. ${ }^{80}$ When used to treat $\mathrm{UCB}$, it has shown to have a tissue sparing effect. ${ }^{81}$ In the case of SCLC, some of the commonly used doses/schedules of chemotherapy in combined chemoradiation are: cisplatin $60 \mathrm{mg} / \mathrm{m}^{2} \mathrm{D} 1$ and etoposide $120 \mathrm{mg} / \mathrm{m}^{2} \mathrm{D} 1-3{ }^{82}$ cisplatin $80 \mathrm{mg} / \mathrm{m}^{2} \mathrm{D} 1$ and etoposide $100 \mathrm{mg} / \mathrm{m}^{2} \mathrm{D} 1-3,{ }^{83}$ carboplatin AUC 5-6 D1 and etoposide $100 \mathrm{mg} / \mathrm{m}^{2}$ D1-3. ${ }^{84,85}$

In a recent meta-analysis of individual patient data in SCLC, carboplatin was demonstrated to be equivalent to cisplatin for patients treated with chemotherapy alone or chemoradiation, but with different toxicity profile. ${ }^{86}$ Carboplatin was associated with more myelosuppression and cisplatin had more nephrotoxicity, neurotoxicity and nausea/emesis. Therefore, depending on a patient's comorbidities and performance status, carboplatin can be used as a substitute for cisplatin in SCLC, and in analogy, may also be considered in SCCB.

Chemotherapy regimens used in SCCB in combination with radiotherapy included: EP; carboplatin+etoposide; vindesine+ifosfamide+cisplatin; cisplatin+doxorubicin+ vincristine+etoposide; and cyclophosphamide+methotrexate+ vinblastine. The doses and schedules were infrequently reported.

In the prospective trial by Bex and colleagues, ${ }^{28} 25$ patients with SCCB were treated similarly to SCLC. For the 17 patients with LD, about $50 \%$ of patients received chemotherapy (cisplatin-containing regimen) and sequential radiotherapy. The patients who received chemoradiation had a median overall survival of 15 months, compared to 14 months with chemotherapy alone. There were no deaths related to locoregional tumour progression. These authors subsequently published a retrospective study in which $47 \%$ of patients with LD developed metastatic disease at 6 months. ${ }^{38}$

Between 1992 and 2002, Asmis and colleagues ${ }^{76}$ identified 12 patients with SCCB, 8 of which had LD. Six of these 8 patients were treated with platinum plus etoposide (4-6 cycles) and radiation (40 Gy/20 fractions to the bladder and draining lymph nodes, followed by a boost of $20 \mathrm{~Gy} / 10$ fractions to the bladder alone). Median survival for all SCCB patients was 19.8 months. One patient was alive at 5 years. ${ }^{76}$

In 1999, Lohrisch and colleagues ${ }^{25}$ reported the results of 10 LD SCCB patients treated with a bladder-sparing approach with chemoradiation. Nine patients had complete response, and 2-year and 5-year overall survival were $70 \%$ and $44 \%$, respectively. Five patients were alive and diseasefree after a median follow-up of 82 months. ${ }^{25}$

Karpaman and colleagues reported one more case, but provided a review of literature up to 2004 of patients treated with chemoradiation. In their report, $52 \%$ of their 23 cases were stage IV. With a median follow-up of 34 months, 70\% were alive, and therefore, the median survival had not been reached. Six patients $(26 \%)$ developed a new primary or recurrence of $U C B$ in the bladder; 3 of these patients were treated with salvage cystectomy. ${ }^{87}$

On analysis of SEER data, efficacy of the bladder sparing approach (TURBT combined with chemoradiation) was compared to combination of cystectomy and chemotherapy. The 5 -year actuarial overall survival rate was $19 \%$ and $26 \%$, respectively, with no difference in overall survival $(p>0.05)$. For patients with localized disease, radiotherapy, when added to TURBT, was related to a statistically significant increase in overall survival. ${ }^{75}$ Chemotherapy had an impact on overall survival in all stages of disease, while radiotherapy only improved it in localized disease.

In a more recent retrospective analysis of SEER, 663 patients with SCCB were identified. The median overall survival for all patients was 12 months $(95 \% \mathrm{Cl}, 10.9-13.1)$. Once patients with stage IV at presentation and patients who were not treated were excluded, there was no significant difference in survival when comparing cystectomy (median overall survival 21 months; $95 \% \mathrm{Cl}, 14.3-27.7)$ to external beam radiation (17 months; $95 \% \mathrm{Cl}, 13.4-20.6)$. Both treatments improved survival on multivariate analysis, with hazard ratios of 0.53 for cystectomy and 0.66 for radiation. ${ }^{68}$

During and after treatment, appropriate follow-up is important to assess for response and potential recurrence. In $U C B$, patients who receive neoadjuvant chemotherapy are usually reassessed with CT scans and cystoscopy after 2 cycles of chemotherapy. If there is evidence of disease progression, patients should proceed directly to cystectomy. ${ }^{88}$ 
For patients treated with bladder-sparing therapy, cystoscopy may be considered as interim assessment after 40 Gy. After completion of radiation, cystoscopy is recommended every 3 months for the first 2 years, then every 6 months for 3 years and then annually. ${ }^{89} \mathrm{~A}$ CT scan of abdomen and pelvis is recommended 6 months after completion of therapy. ${ }^{89}$

\section{Treatment of extensive disease}

\section{Chemotherapy}

Patients with ED SCCB have a poor outcome. In the previously described SEER data, ${ }^{68}$ patients with metastatic disease at diagnosis had a median survival of 5 months $(95 \% \mathrm{Cl}$, 3.7-6.3). In addition, Ismaili and colleagues reported that patients with recurrent and metastatic SCCB had a median overall survival of 7.6 months. ${ }^{26}$ Therefore, the role of chemotherapy in this setting is palliative.

The importance of platinum-based chemotherapy is reinforced by Mackey and colleagues; on multivariate analysis, they found that only cisplatin containing chemotherapy predicted prolonged survival (hazard ratio 0.15). ${ }^{39}$ These data highlight that the high mortality of SCCB is related to the metastatic potential, reinforcing the role of chemotherapy in the therapeutic arsenal.

Chemotherapy, even when adjusted for stage, is an independent prognostic factor for survival. ${ }^{28}$ In most of the studies, intravenous chemotherapy was given with regimens usually used for SCLC (Table 2, Table 3). For first-line ED SCLC, there are several options given for 4 to 6 cycles, including: cisplatin $75 \mathrm{mg} / \mathrm{m}^{2} \mathrm{D} 1$ and etoposide $100 \mathrm{mg} /$ $\mathrm{m}^{2} \mathrm{D} 1-3,{ }^{90}$ cisplatin $80 \mathrm{mg} / \mathrm{m}^{2} \mathrm{D} 1$ and etoposide $80 \mathrm{mg} / \mathrm{m}^{2}$ D1-3, ${ }^{91}$ carboplatin AUC 5-6 D1 and etoposide $100 \mathrm{mg} / \mathrm{m}^{2}$ D1-3, ${ }^{92}$ cisplatin $60 \mathrm{mg} / \mathrm{m}^{2} \mathrm{D} 1$ and irinotecan $60 \mathrm{mg} / \mathrm{m}^{2} \mathrm{D} 1$, D8 and D15, ${ }^{93}$ carboplatin AUC 5 D1 and irinotecan $50 \mathrm{mg} /$ $\mathrm{m}^{2} \mathrm{D} 1, \mathrm{D} 8$ and D15. ${ }^{94}$ Patients' performance status, renal function and comorbidities will play a key role in deciding which chemotherapy option to choose.

\section{Prophylactic cranial irradiation}

In patients with SCLC, the rate of brain metastasis is as high as $60 \%$, presenting within 2 to 3 years after primary treatment. ${ }^{95}$ Prophylactic cranial irradiation decreases this rate to $26 \%$ to $50 \%$, and has been shown to result in improved

\section{Treatment of limited SCCB}

\section{Recommendation:}

Chemotherapy combined with surgery

Neoadjuvant chemotherapy with cisplatin and etoposide for 4 cycles followed by radical cystectomy. Level 3, Grade C

Potential schedules include, but are not limited to: cisplatin $60-80 \mathrm{mg} / \mathrm{m}^{2}$ D1 and etoposide $100-120 \mathrm{mg} / \mathrm{m}^{2}$ IV, D1-3 q21 days, followed by surgery (radical cystectomy). Level 3, Grade C

In patients with contraindications to cisplatin-based regimen, carboplatin should be used (carboplatin AUC 5-6 D1 and etoposide $100 \mathrm{mg} / \mathrm{m} 2$ IV, D1-3). Level 4 Grade C

Reassessment of disease with chest, abdomen and pelvis CT-scans after 2 cycles of chemotherapy and again prior to surgery, to assess for response to treatment, should be done.Level 4 Grade $C$

There is little data supporting adjuvant chemotherapy with EP, but this can be considered at physician's discretion. Level 4, Grade D

\section{Bladder-sparing therapy: Chemotherapy and radiation}

Potential chemotherapy schedules include, but are not limited to: Four to six cycles of EP (cisplatin $75 \mathrm{mg} / \mathrm{m}^{2} \mathrm{D} 1$ and etoposide $100 \mathrm{mg} / \mathrm{m}^{2}$ IV) D1-3) or cisplatin $80 \mathrm{mg} / \mathrm{m}^{2}$ D1 and etoposide $80 \mathrm{mg} / \mathrm{m}^{2} \mathrm{IV}, \mathrm{D} 1-3, \mathrm{q} 21$ days, in combination with radiotherapy, $60 \mathrm{~Gy}$ in 30 fractions, commencing at Cycle 1-2 as done for SCLC. Level 3, Grade C

IMRT could be considered. Level 4, Grade D

In case of contraindication to cisplatin, carboplatin (carboplatin AUC 5-6 on D1 and etoposide $100 \mathrm{mg} / \mathrm{m}^{2}$ IV, D1-3) should be used. Level 4 Grade C

TURBT for removal of any large tumour burden prior to start treatment, as done for UCB and frequently done in the SCCB, should be performed. Note: TURBT alone or intravesical therapy are not considered adequate treatment. Level 4, Grade $C$ 


\section{Treatment of extensive disease SCCB}

Recommendation: Platinum-based chemotherapy, for 4-6 cycles.

Potential regimens include EP (cisplatin $75 \mathrm{mg} / \mathrm{m}^{2}$ D1 and etoposide $100 \mathrm{mg} / \mathrm{m}^{2} \mathrm{IV}$, D1-3; cisplatin $80 \mathrm{mg} / \mathrm{m}^{2} \mathrm{D} 1 \mathrm{and}$ etoposide $80 \mathrm{mg} / \mathrm{m}^{2} \mathrm{IV}$, D1-3) q21 days, if no major comorbidities, or contraindication to chemotherapy.

Based on patient comorbidities, carboplatin (AUC 5-6 D1) could be used in combination with etoposide (100 mg/m² IV, D1-3), q21 days. Level 4 Grade $C$.

\section{Role for prophylactic cranial irradiation}

Recommendation: Prophylactic brain radiation may be considered and discussed with patients with limited and extensive disease who have had a good clinical response to treatment.

This is recommended, despite the lack of efficacy proof, based on poor prognosis once brain metastases develop and extrapolation of the SCLC data. Level 4 Grade $C$.

\section{Management of refractory or relapsed disease}

\section{Recommendation:}

Patients should be assessed with cystoscopy to determine the histological component of recurrence, especially in cases with initial mixed histology. However, in patients treated with bladder-sparing therapy, regardless of pathology, i.e. UCB or SCCB, salvage cystectomy should be considered for local recurrences. Level 4 Grade $C$

Patients found to have distant metastatic disease on imaging could be treated with platinum-based chemotherapeutic agents as outlined above. The participation in clinical trials of novel agents, when possible, should be considered. Level 4 Grade $C$

Patients who have received recent $(<3-6$ months) prior platinum-based chemotherapy could be considered for second line agents such topotecan (oral $2.3 \mathrm{mg} / \mathrm{m}^{2} /$ day for 5 days, q21 days, or IV $1.5 \mathrm{mg} / \mathrm{m}^{2} /$ day for 5 days, q21 days) or CAV (cyclophosphamide $1,000 \mathrm{mg} / \mathrm{m}^{2}$, doxorubicin $45 \mathrm{mg} / \mathrm{m}^{2}$, and vincristine $2 \mathrm{mg}$, D1, q21 days) as extrapolation from SCLC. However there is no data to validate this approach. The participation in clinical trials of novel agents, when possible, should be considered. Given poor prognosis, consider best supportive care for patients with poor performance status. Level 4 Grade $C$

disease-free and overall survival in SCLC, ${ }^{89}$ at the potential cost of neurocognitive impairment. ${ }^{96}$ The true incidence of brain metastasis in SCCB is not clear, but seems to be lower than in SCLC. As described previously, data from a large retrospective series of 342 patients show a cumulative incidence of $11 \% .^{30}$ The development of brain metastasis correlates with stage, as documented by Siefer-Radtke and colleagues. ${ }^{31}$ They found that brain metastases occurred in $8 / 16(50 \%)$ of patients with either bulky or metastatic disease $(p=0.004)$. In the reviewed trials of SCCB, prophylactic cranial irradiation was inconsistently used, and there is no data on improvement of quality of life, progression-free, disease-free or overall survival.

\section{Refractory or relapsed disease}

Distant relapse occurs frequently and early despite chemotherapy and local therapy, often within 4 months. With regard to local recurrence, the literature is poor in providing clear information on how to proceed. However, rates of relapse of $0-25 \%$ have been reported, and these seem to be higher when the initial approach involved cystectomy. ${ }^{38,97}$ Ismaili and colleagues ${ }^{98}$ reported 15 patients with recurrent or developed metastatic SCCB. Twelve had previously localized disease (11 treated with radical cystectomy). Patients were primarily treated with platinum-based chemotherapy, but 4 received chemoradiation for localized recurrence. The median overall survival for all patients was 7.6 months.

There are several case reports of patients developing a second bladder cancer primary after treatment with chemotherapy or radiation for SCCB, with urothelial carcinoma being the most common histology. ${ }^{38,97}$ Lohrisch and colleagues described an incidence rate of $60 \%$ at 2 years for second primary UCB following successful treatment of SCCB (3 of 5 long-term survivors). ${ }^{25}$ There are other reports on recurrences/secondary bladder cancers occurring 24 to 50 months after treatment, with survival data up to 8 years with salvage cystectomy. ${ }^{25,38}$ Due to these documented late recurrences, long-term follow-up with cystoscopy is suggested..$^{38}$ There are no specific guidelines on cystoscopy frequencies 
for follow-up in SCCB. However, for UCB, it is usually recommended at 3 months, with urine cytology, after chemoradiation, and every 3 to 6 months for the following years. ${ }^{89}$

In recurrent SCLC, re-administration of the first-line chemotherapy regimen may be considered if more than 3 to 6 months have passed. The most frequently used second-line regimens are topotecan or cyclophosphamide, doxorubicin, and vincristine (CAV). In SCLC, topotecan has comparable response rates and survival to CAV (cyclophosphamide $1,000 \mathrm{mg} / \mathrm{m}^{2}$, doxorubicin $45 \mathrm{mg} / \mathrm{m}^{2}$, and vincristine $2 \mathrm{mg}$, D1, every 21 days) with less toxicity. ${ }^{99}$ Oral topotecan $2.3 \mathrm{mg} / \mathrm{m}^{2} /$ day for 5 days, when compared to intravenous $1.5 \mathrm{mg} / \mathrm{m}^{2} /$ day for 5 days every 21 days, resulted in comparable median survival at 2 years, therefore constituting an alternative to the intravenous formulation. ${ }^{100}$

\section{Conclusion}

SCCB is an uncommon and aggressive disease. Patients should be referred to centres with more experience in treating this disease, and combined modality therapy should be used when possible. There is lack of prospective trials in this setting to provide better quality information, and further trials are required. A rare disease consortium would be the best way to achieve this. It would be valuable to include these patients in a registry to collect data regarding management and outcomes to better treat this rare disease.

Competing interests: None declared.

This paper has been peer-reviewed.

Acknowledgements: Other members of CAGMO who participated in the discussion of this guideline: Dean Ruether, Daniel Heng, Kim Chi, Naveen Basappa, Axel Tosikyan, Susan Ellard, Pawel Zalewski, Bernie Eigl, Tina Cheng, Anthony Joshua and Daygen Finch.

\section{References}

1. Cicin I, Karagol H, Uzunoglu $S$ et al. Extrapulmonary small-cell carcinoma compared with small-cell lung carcinoma: a retrospective single-center study. Cancer 2007;1 10:1068-76. hittp://dx.doi.org/10.1002/ cncr.22887

2. Spira A, Ettinger DS. Multidisciplinary Management of Lung Cancer. N Engl J Med 2004;350:379-92. http://dx.doi.org/10.1056/NEJMra035536

3. Johnson BE, Grayson J, Makuch RW, et al. Ten-year survival of patients with small-cell lung cancer treated with combination chemotherapy with or without irradiation. J Clin Oncol 1990;8:396-401.

4. Duguid JB, Kennedy AM. Oat-cell tumors of mediastinal glands. Path Bacterial 1930;33:93-9.

5. Haider K, Shahid RK, Finch D, et al. Extrapulmonary small cell cancer: a Canadian provinces' experience. Cancer 2006;107:2262-9. http://dx.doi.org/10.1002/cncr.22235

6. Ferlito $A$, Rinaldo $A$. Primary and secondary small cell neuroendocrine carcinoma of the larynx: a review. Head Neck 2008;30:518-24. http://dx.doi.org/10.1002/hed.20797

7. Cramer SF, Aikawa M, Cebelin M. Neurosecretory granules in small cell invasive carcinoma of the urinary bladder. Cancer 1981;47:724-30. http://dx.doi.org/10.1002/1097-0142(19810215)47:4<724::AIDCNCR2820470417>3.0.C0;2-2
8. Capella C, Eusebi V, Rosai J. Pulmonary oat cell carcinoma of the kidney. Am I Surg Pathol 1984;8:85561. http://dx.doi.org/10.1097/00000478-198411000-00006

9. Patil S, Kaza RCM, Kakkar AK, et al. Case report: Small Cell Carcinoma of the Renal Pelvis: A Case Report and Review of the Literature. ISRN Urology 2011;786505. http://dx.doi.org/10.5402/2011/786505. Epub 2011 Apr 28

10. Ordonez NG, Khorsand J, Ayala AG, et al. Oat cell carcinoma of the urinary tract: and immunohistochemical and electron microscopic study. Cancer 1986;58:2519-30. http://dx.doi.org/10.1002/10970142(19861201)58:11 <2519::AID-CNCR2820581127>3.0.C0;2-0

11. Paner GP, BarkanGA, Mehta V, et al. Urachal Carcinomas of the Non glandular type: Salient Features and Considerations in Pathologic Diagnosis. Am J Surg Pathol 2012;36:432-42. http://dx.doi.org/10.1097/ PAS.0b013e31823fe49c

12. Kanagarajah $P$, Ayyathurai $R$, Saleem U, et al. Small Cell Carcinoma Arising from the Bulbar Urethra: A Case Report and Literature Review. Urol Int 201 1;88:477-9. http://dx.doi.org/10.1159/000332154

13. Tetu B, Ro JY, Ayala AG, et al. Small cell carcinoma of the prostate: Part l: A clinicopathologic study of 20 cases. Cancer 1987;59:1803-9. http://dx.doi.org/10.1002/1097-0142(19870515)59:10<1803::AIDCNCR2820591019>3.0.C0;2-X

14. Blomious CE, Vos W, De Voogt HJ, et al. Small cell carcinoma of the urinary bladder: A clinicopathologic, morphometric, immunohistochemical, and ultrastructural study of 18 cases. Cancer 1989;64:1347-57. http://dx.doi.org/10.1002/1097-0142(19890915)64:6<1347::AID-CNCR2820640629>3.0.C0;2-

15. Holmang S, Borghede $G$, Johanson $S$, et al. Primary small cell carcinoma of the bladder: A report of 25 cases. J Urol 1995;153:1820-2. http://dx.doi.org/10.1016/S0022-5347(01)67320-8

16. National Cancer Institute. SEER Survival Monograph. http://www.seer.cancer.gov/publications/survival/ surv_bladder.pdf. Accessed January 31, 2013.

17. Oxford Centre for Evidence-based Medicine Levels of Evidence. http://www.cebm.net/index. aspx?0=1023. Accessed January 31, 2013.

18. Brouwers MC, Kho ME, Browman GP, et al. AGREE II: advancing guideline development, reporting and evaluation in health care. CMAJ 2010;182:E839-42. http://dx.doi.org/10.1503/cmaj.090449

19. The Appraisal of Guidelines for Research and Evaluation. http://www.agreetrust.org. Accessed January 31, 2013.

20. Cheng L, Pan $C X$, Yang XJ, et al. Small cell carcinoma of the urinary bladder: A clinicopathologic analysis of 64 patients. Cancer 2004;101:957-62. http://dx.doi.org/10.1002/cncr.20456

21. Ismaili N, Elkarak F, Heudel PE, et al. Small cell cancer of the bladder: The Leon-Berard Cancer Centre experience. Indian J Urol 2008:24:494-7. http://dx.doi.org/10.4103/0970-1591.44255

22. Choong NW, Quevedo JF, Kaur JS. Small cell carcinoma of the urinary bladder. The Mayo Clinic experience. Cancer 2005;103:1 172-8. http://dx.doi.org/10.1002/cncr.20903

23. Abrahams NA, Moran C, Reyes AO, et al. Small cell carcinoma of the bladder: A contemporary clinicopathological study of 51 cases. Histopathology 2005;46:57-63. http://dx.doi.org/10.1111/j.13652559.2004.01980.x

24. Grignon DJ, Ro JY, Ayala, et al. Small cell carcinoma of the urinary bladder. A clinicopathologic analysis of 22 cases. Cancer 1992;69:527-36. http://dx.doi.org/10.1002/1097-0142(19920115)69:2<527::AlDCNCR2820690241>3.0.C0;2-7

25. Lohrisch C, Murray N, Pickles T, et al. Small cell carcinoma of the bladder: Long term outcome with integrated chemoradiation. Cancer 1999;86:2346-52. http://dx.doi.org/10.1002/(SICI) 10970142(19991201)86:11<2346::AID-CNCR24>3.0.C0;2-5

26. Ismaili $\mathrm{N}$, Ghanem $\mathrm{S}$, Mellas N, et al. Small cell carcinoma of the urinary bladder: a case report and review of the literature. J Cancer Res Ther 2009;5:133-6. http://dx.doi.org/10.4103/0973-1482.52790

27. Quek ML, Nichols PW, Yamzon J, et al. Radical cystectomy for primary neuroendocrine tumors of the bladder: the University of Southern California experience. J Urol 2005;174:93-6. http://dx.doi. org/10.1097/01.ju.0000162085.20043. If

28. Bex A, Nieuwenhuijzen JA, Kerst $M$, et al. Small cell carcinoma of bladder: a single-center prospective study of 25 cases treated in analogy to small cell lung cancer. Urology 2005;65:295-9. http://dx.doi. org/10.1016/i.urology.2004.09.049

29. Siefker-Radtke A0, Dinney $\mathrm{CP}$, Abrahams NA, et al. Evidence supporting preoperative chemotherapy for small cell carcinoma of the bladder: a retrospective review of the M.D. Anderson cancer experience. J Urol 2004;172:481-4. http://dx.doi.org/10.1097/01.ju.0000132413.85866.fc

30. Bex A, Sonke GS, Pos FJ, et al. Symptomatic brain metastases from small-cell carcinoma of the urinary bladder: The Netherlands Cancer Institute experience and literature review. Ann Oncol 2010;21:2240-5. http://dx.doi.org/10.1093/annonc/mdq225

31. Siefker-Radtke AO, Kamat AM, Grossman HB, et al. Phase II clinical trial of neoadjuvant alternating doublet chemotherapy with ifosfamide/doxorubicin and etoposide/cisplatin in small-cell urothelial cancer. J Clin Oncol 2009;27:2592-7. http://dx.doi.org/10.1200/JC0.2008.19.0256

32. Reyes CV, Soneru I. Small cell carcinoma of the urinary bladder with hypercalcemia. Cancer 1985;56:2530-3. http://dx.doi.org/10.1002/1097-0142(19851115)56:10<2530::AIDCNCR2820561035>3.0.C0;2-4 
33. Abbas $F$, Civantos $F$, Benedetto $P$, et al. Small cell carcinoma of the bladder and prostate. Urology1995;46:617-30. http://dx.doi.org/10.1016/50090-4295(99)80290-8

34. Eble JN, Sauter G, Epstein Jl, et al. World Health Organization Classification of Tumours: Pathology and Genetics of Tumours of the Urinary System and Male Genital Organs. Lyon: IARC Press; 2004. hittp:// www.iarc.fr/en/publications/pdfs-online/pat-gen/bb7/BB7.pdf. Accessed January 31, 2013.

35. Bajetta $E$, Catena $L$, Procopio $G$, et al. Is the new WHO classification of neuroendocrine tumours useful for selecting an appropriate treatment? Ann Oncol 2005;16:1374-80. http://dx.doi.org/10.1093/ annonc/mdi258

36. Mills SE, Wolfe JT 3rd, Weiss MA, et al.Small cell undifferentiated carcinoma of the urinary bladder. A lightmicroscopic, immunocytochemical, and uttrastructural study of 12 cases. Am J Surg Pathol 1987;11:60617. http://dx.doi.org/10.1097/00000478-198708000-00004

37. Ali SZ, Reuter VE, Zakowski MF. Small cell neuroendocrine carcinoma of the urinary bladder. A clinico-pathologic study with emphasis on cytologic features. Cancer 1997; 79:356-61. http://dx.doi.org/10.1002/ (SICl) 1097-0142(19970115)79:2<356::AID-CNCR19>3.0.C0;2-\#

38. Bex A, de Vries R, Pos F, et al. Long-term survival after sequential chemoradiation for limited disease small cell carcinoma of the bladder. World J Urol 2009; 27:101-6. http://dx.doi.org/10.1007/ s00345-008-0304-x

39. Mackey JR, Au HJ, Hugh J et al. Genitourinary small cell carcinoma: determination of clinical and therapeutic factors associated with survival. J Urol 1998; 159:1624-9. http://dx.doi.org/10.1097/00005392 199805000-00058

40. Trias I, Algaba F, Condom E, et al. Small cell carcinoma of the urinary bladder. Presentation of 23 cases and review of 134 published cases. Eur Urol 2001; 39:85-90. http://dx.doi.org/10.1159/000052417

41. Soriano P, Navarro S, Gil M, A. Small-cell carcinoma of the urinary bladder. A clinicopathological study of ten cases. Virchows Arch 2004; 445:292-7. http://dx.doi.org/10.1007/s00428-004-1041-1

42. Zhao X, Flynn EA. Small Cell Carcinoma of the Urinary Bladde:r A Rare, Aggressive Neuroendocrine Malignancy. Arch Pathol Lab Med 2012; 136:1451-9. http://dx.doi.org/10.5858/arpa.2011-0267-RS

43. Agoff SN, Lamps LW, Philip AT, et al. Thyroid transcription factor-1 is expressed in extrapulmonary small cell carcinomas but not in other extrapulmonary neuroendocrine tumors. Mod Pathol 2000; 13:238-42. http://dx.doi.org/10.1038/modpathol.3880044

44. Jones TD, Kernek KM, Yang XJ et al. Thyroid transcription factor 1 expression in small cell carcinoma of the urinary bladder: an immunohistochemical profile of 44 cases. Hum Pathol 2005; 36:718-23. http:// dx.doi.org/10.1016/i.humpath.2005.04.007

45. Wang X, MacLennan GT, Lopez-Beltran A, et al. Small cell carcinoma of the urinary bladder - histogenesis, genetics, diagnosis, biomarkers, treatment, and prognosis. Appl Immunohistochem Mol Morphol 2007;15:8-18. http://dx.doi.org/10.1097/01.pai.0000213106.12731.d7

46. Iczkowski KA, Shanks JH, Allsbrook WC, et al. Small cell carcinoma of urinary bladder is differentiated from urothelial carcinoma by chromogranin expression, absence of CD44 variant 6 expression, a unique pattern of cytokeratin expression, and more intense gamma-enolase expression. Histopathology 1999; 35:150-6. http://dx.doi.org/10.1046/j.1365-2559.1999.00715.x

47. Planchard D, Le Péchoux C. Small cell lung cancer: new clinical recommendations and current status of biomarker assessment. Eur J Cancer 2011; 47:S272-83. http://dx.doi.org/10.1016/S0959$8049(11) 70173-3$

48. Dabbs, DJ. Immunohistology of metastatic carcinoma of unknown primary. In: Diagnostic Immunohistochemistry, 2nd ed, Dabbs DJ, editor. Elsevier, Philadelphia 2006. p. 180.

49. Johanson L. Histopathologic classification of lung cancer: Relevance of cytokeratin and TTF-1 immunophenotyping. Annals of Diagnostic Pathology 2004; 8: 259-67. http://dx.doi.org/10.1016/i. anndiagpath.2004.07.001

50. Ebele JN, Sauter G, Epstein II, Sesterhenn IA, eds. WHO Classification of Tumors: 2004 Pathology and Genetics of Tumours of the Urinary System and Male Genital Organs. Lyon, France: International Agency for Research on Cancer; 2004.PP.135-6

51. Pan CX, Yang XJ, Lopez-Beltran A, et al. c-kit Expression in small cell carcinoma of the urinary bladder: prognostic and therapeutic implications. Mod Pathol 2005; 18:320-3. http://dx.doi.org/10.1038/ modpathol. 3800318

52. Hirsch FR, Varella-Garcia M, Bunn PA Jr, et al. Epidermal growth factor receptor in non-small-cell lung carcinomas: correlation between gene copy number and protein expression and impact on prognosis. J ClinOncol 2003; 21:3798-807. http://dx.doi.org/10.1200/JC0.2003.11.069

53. Wang HL, Lu DW. Detection of human papillomavirus DNA and expression of p16, Rb, and p53 proteins in small cell carcinomas of the uterine cervix. Am J Surg Pathol 2004; 28:901-8. http://dx.doi. org/10.1097/00000478-200407000-00009

54. Wang X, Jones TD, Maclennan GT, et al. P53 expression in small cell carcinoma of the urinary bladder: biological and prognostic implications. Anticancer Res 2005; 25:2001-4.

55. Zelen M. Keynote address on biostatistics and data retrieval. Cancer Chemother Rep 3 1973; 4:31-42.
56. Shepherd FA, Crowley J, Van Houtte P et al. The International Association for the Study of Lung Cancer lung cancer staging project: proposals regarding the clinical staging of small cell lung cancer in the forthcoming (seventh) edition of the tumor node, metastasis classification for lung cancer. J Thorac Oncol 2007; 2:1067-77. http://dx.doi.org/10.1097/JT0.0b013e31815bdc0d

57. Urinary bladder. In: Edge SB, Byrd DR, Compton CC, et al., eds.: AJCC Cancer Staging Manual. 7 th ed. New York, NY: Springer, 2010, p 497-505.

58. Argiris A, Murren JR. Staging and clinical prognostic factors for small-cell lung cancer. Cancer J 2001; 7:437-47.

59. American College of Radiology ACR Appropriateness Criteria. Available from: http://www.acr.org/ / media/F2F4EEEC9A844548AAB63AA0999A4ED7.pdf

60. Takeuchi $M$, Sasaki $S$, Ito $M$ et al. Urinary bladder cancer: diffusion weighted MR imaging - accuracy for diagnosing T stage and estimating histologic grade. Radiology 2009; 251: 112-21. http://dx.doi. org/10.1148/radiol.2511080873

61. Kim JK, Park SY, Ahn HJ, et al. Bladder cancer: analysis of multi-detector row helical CT nhancement pattern and accuracy in tumor detection and perivesical staging. Radiology 2004; 231:725-31. http:// dx.doi.org/10.1148/radiol.2313021253

62. Kim B, Semelka RC, Ascher SM, et al. Bladder tumor staging: comparison of contrast-enhanced CT, Tl-and T2-weighted MR imaging, dynamic gadolinium-enhanced imaging, and late gadolinium-enhanced imaging. Radiology 2004; 193: 239-45.

63. American College of Radiology ACR Appropriateness Criteria. Available from: http://www.acr.org/ / media/ACR/Documents/AppCriteria/Oncology/PrelrradiationEvaluationBrainMetastases.pdf

64. Akeson P, Larsson EM, Kristoffersen DT, et al. Brain metastases-comparison of gadodiamide injectionenhanced MR imaging at standard and high dose, contrast-enhanced CT and non-contrast-enhanced MR imaging. Acta Radiol 1995; 36:300-6. http://dx.doi.org/10.3109/02841859509177639

65. PET Imaging in Small Cell Lung Cancer - Cancer Care Ontario. Available from: https://www.cancercare. on.ca/common/pages/UserFile.aspx?fileld=43157

66. Fischer BM, Mortensen J, Langer SW, et al. A prospective study of PET/CT in initial staging of small cell lung cancer: comparison with CT, bone scintigraphy and bone marrow analysis. Ann Oncol 2007; 18:338-45. http://dx.doi.org/10.1093/annonc/mdl374

67. Brink I, Schumacher T, Mix M, et al. Impact of [18F]FDG-PET on the primary staging of small-cell lung cancer. Eur J Nudl Med Mol Imaging 2004; 31:1614-20. http://dx.doi.org/10.1007/s00259-004-1606-x

68. Schreiber D, Rineer J, Weiss J, et al. Characterization and Outcomes of Small Cell Carcinoma of the Bladder Using the Surveillance, Epidemiology, and End Results Database. Am I Clin Oncol 2012; Epub ahead of print. http://dx.doi.org/10.1097/COC.0b013e3182438c71

69. National Cancer Care Network Guidelines. Available from: http://www.nccn.org/professionals/physician_gls/PDF/bladder.pdf Accessed November 19, 2011.

70. Kalaiah $M$, I. Aldoss, W. Gonsalves et al. Small cell carcinoma of the bladder among patients in the Veterans Affairs Health System. J Clin Oncol 2010, 28(15S);Abstract el5073

71. Mukesh M, Cook N, Hollingdale AE, et al. Small cell carcinoma of the urinary bladder: a 15-year retrospective review of treatment and survival in the Anglian Cancer Network. BJU Int. 2009; 103:747-52. http://dx.doi.org/10.1111/i.1464-410X.2008.08241.x

72. Lynch SP, Shen yu, Kamat A et al. Neoadjuvant chemotherapy in small cell urothelial cancer improves pathologic downstaging and long-term outcomes: Results from a retrospective study at the M. D. Anderson Cancer Center. Eur Urol 2012; Apr 17. [Epub ahead of print]

73. Canadian Guidelines for Treatment of Non-Muscle Invasive Bladder Cancer - A Focus on Intravesical Therapy. Available from: hittp://www.cua.org/userfiles/files/Non-Muscle\%20Invasive\%20Bladder\%20 Cancer.pdf-Access date July 2011

74. Balar A, Bakorin DF, Milowsky MI. Management of invasive bladder cancer in patients who are not candidates for or decline cystectomy. Ther Adv Urol 2011; 3: 107-17.

75. Koay EJ, Teh BS, Paulino AC, et al. Treatment trends and Outcomes of Small-Cell Carcinoma of the Bladder. Int J Radiat Oncol Biol Phys 2011; 83:64-70.

76. Asmis TR, Reaume MN, Dahrouge $S$, et al. Genitourinary small cell carcinoma: a retrospective review of treatment and survival patterns at The Ottawa Hospital Regional Cancer Center. BJU Int 2006; 97(4):711-5

77. Coppin CM, Gospodarowicz MK, James K. Et al. Improved local control of invasive bladder cancer by concurrent cisplatin and preoperative or definitive radiation. The National Cancer Institute of Canada Clinical Trials Group. J Clin Oncol 1996; 14:2901-7.

78. Sengeløv L, von der Maase HRadiotherapy in bladder cancer. Radiother Oncol 1999; 52:1-14. http:// dx.doi.org/10.1016/S0167-8140(99)00090-0

79. Mangar SA, Logue JP, Shanks JH, et al. Small cell carcinoma of the urinary bladder: 10-year experience. Clin Oncol (R Coll Radiol) 2004; 16:523-7. 
Moretto et al.

80. D.P. D'Souza, R.B. Rumble, A. Fyles, B, et al. The Role of IMRT in Gynecologic Cancers. Evidence basedseries, Cancer care Ontario. Available from: https://www.cancercare.on.ca/common/pages/UserFile. aspx? fileld $=87003$

81. Sondergaard J, Hoyer $M$, Petersen JB, et al. The normal tissue sparing obtained with simultaneous treatment of pelvic lymph nodes and bladder using intensity-modulated radiotherapy. ActaOncol 2009; 48: 238-44.

82. Turrisi AT 3rd, Kim K, Blum R, et al. Twice-daily compared with once-daily thoracic radiotherapy in limited small-cell lung cancer treated concurrently with cisplatin and etoposide. N Engl J Med 1999; 340: 265-71.

83. Takada M, Fukuoka $M$, Kawahara $M$, et al. Phase III study of concurrent versus sequential thoracic radiotherapy in combination with cisplatin and etoposide for limited-stage small-cell lung cancer: results of the Japanese Clinical Oncology Group Study 9104. J Clin Oncol 2002; 20:3054-60.

84. Okamoto H, Watanabe K, Kunikane $\mathrm{H}$, et al.: Randomised phase III trial of carboplatin plus etoposide vs split doses of cisplatin plus etoposide in elderly or poor-risk patients with extensive disease small-cell lung cancer: ICOG 9702. Br I Cancer 2007; 97: 162-9.

85. Skarlos DV, Samantas E, Briassoulis E, et al. Randomized comparison of early versus late hyperfractionated thoracic irradiation concurrently with chemotherapy in limited disease small-cell lung cancer: a randomized phase Il study of the Hellenic Cooperative Oncology Group (HeCOG). Ann Oncol 2001; 12:1231-8.

86. Rossi A, Di Maio M, Chiodini P,et al. Carboplatin- or cisplatin-based chemotherapy in first-line treatment of small-cell lung cancer: the COCIS meta-analysis of individual patient data. J Clin Oncol 2012; 30:1692-8.

87. Karpman E, Goldberg Z, Saffarian, et al. Analysis of treatment for small cell cancer of the bladder and report of three cases. Urology 2004; 64:494-8.

88. Bladder Cancer - London Health Sciences Centre. Available from: http://www.Ihsc.on.ca/Health_ Professionals/LRCP/Oncology Practice Guidelines/Bladderguidelinesv4June22 GSBTSfinal.pdf

89. Bladder Cancer - Alberta Health Services.Availabe from: http://www.albertahealthservices.ca/hp/itthpcancer-guide-gu002-bladder.pdf

90. Sundstrom S, Bremnes RM, Kaasa $\mathrm{S}$, et al. Cisplatin and etoposide regimen is superior to cyclophosphamide, epirubicin and vincristine regimen in small -cell lung cancer: results from a randomized phase II trial with 5 years follow-up. J Clin Oncol 2002; 20: 4665-72

91. Ihde DC, Mulshine JL, Kramer BS et al. Prospective randomized comparison of high dose and standard dose etoposide and cisplatin chemotherapy in patients with extensive-stage small-cell lung cancer. J Clin Oncol 1994; 12: 2022-34

92. Okamoto H, Watanabe K, Nishiwaki Y, et al. Phase II study of area under the plasma-concentrationversus -time curve based carboplatin plus standard dose intravenous etoposide in elderly patients with small cell lung cancer. J Clin Oncol 1999; 17:354-5.

93. Noda $K$, Nishiwaki $Y$, kawahara $M$, et al. Irinotecan plus cisplatin compared with etoposide plus cisplatin for extensive small-cell lung cancer. N Engl J Med 2002; 346: 85-91

94. Schmittel A, Sebastian M, Fischer von Weikersthal L, et al. A German multicenter, randomized phase III trial comparing irinotecan-carboplatin with etoposide-carboplatin as first-line therapy for extensive-disease small-cell lung cancer. Ann Oncol 2011; 22:1798-804

95. Auperin A, Arriagada R, Pignon JP et al. Prophylactic cranial irradiation for patients with small-cell lung cancer in complete remission. Prophylactic Cranial Irradiation Overview Collaborative Group. N Engl J Med 1999; 341: 476-84

96. Ahles TA, Silberfarb PM, Herndon J, et al. Psychologic and neuropsychologic functioning of patients with limited small-cell lung cancer treated with chemotherapy and radiation therapy with or without warfarin: a study by the Cancer and Leukemia Group B. J Clin Oncol 1998; 16:1954-60.

97. Alva AS, Hanauer D, Hussain M, Smith DC. Outcomes following neoadiuvant chemotherapy and cystectomy in localized small cell bladder cancer: The University of Michigan experience. 2010 Genitourinary Cancers Symposium. Abstract №: 287

98. Ismaili N, Heudel PE, Elkarak $F$ et al. Outcome of recurrent and metastatic small cell carcinoma of the bladder. BMC Urol 2009 Jun 6; 9:4.

99. von Pawel J, Schiller JH, Shepherd FA, et al. Topotecan versus cyclophosphamide, doxorubicin, and vincristine for the treatment of recurrent small-cell lung cancer. J Clin Oncol 1999; 17:658-67

100. Eckardt JR, von Pawel J, Pujol JL, et al. Phase III study of oral compared with intravenous topotecan as second-line therapy in small-cell lung cancer. J Clin Oncol 2007; 25:2086-92

Correspondence: Dr. Christina Canil, Division of Medical Oncology, The Ottawa Hospital Cancer Centre, 501 Smyth Road, Ottawa, ON K1H 8L6; ccanil@0ttawahospital.on.co 